\title{
Effect of temperature and salinity on otolith element incorporation in juvenile gray snapper Lutjanus griseus
}

\author{
Gretchen Bath Martin ${ }^{1,2, *}$, Mark J. Wuenschel ${ }^{1,3}$ \\ ${ }^{1}$ NOAA/NOS/NCCOS Center for Coastal Fisheries and Habitat Research, 101 Pivers Island Road, Beaufort, \\ North Carolina 28516, USA \\ ${ }^{2}$ Present address: NOAA Fisheries Service, Southeast Fisheries Science Center, Center for Coastal Fisheries and Habitat \\ Research, 101 Pivers Island Road, Beaufort, North Carolina 28516, USA \\ ${ }^{3}$ Present address: Rutgers University, Institute of Marine and Coastal Sciences, Marine Field Station, 800 c/o 132 \\ Great Bay Boulevard, Tuckerton, New Jersey 08087-2004, USA
}

\begin{abstract}
Otolith chemistry provides one approach for identifying the relative contribution of juveniles from different nursery habitats to adult populations. The goal of this study was to validate otolith element incorporation by quantifying the relation between otolith and water element concentrations $(\mathrm{Sr} / \mathrm{Ca}, \mathrm{Mg} / \mathrm{Ca}, \mathrm{Mn} / \mathrm{Ca}$, and $\mathrm{Ba} / \mathrm{Ca}$ ) as a function of differences in water temperature and salinity using juvenile gray snapper Lutjanus griseus, a reef fish that inhabits estuarine and nearshore habitats as juveniles. We investigated the effects of 20 different temperature $\left(18,23,28,33^{\circ} \mathrm{C}\right)$ and salinity $(5,15,25,35,45)$ combinations on otolith element incorporation (partition coefficient $D$ ) in L. griseus. Temperature and salinity had significant effects on $D_{\mathrm{Sr}}$ but no significant effect on $D_{\mathrm{Mg}}$ or $D_{\mathrm{Mn}}$ however, salinity had a significant effect on $D_{\mathrm{Ba}}$. The broad range of temperatures and salinities used in the present study encompasses those occupied by juveniles in the wild and therefore provides a realistic test for using otolith chemistry to infer environmental history of individual gray snapper. Element incorporation and the effects of temperature and salinity on element incorporation differ among fish species, limiting development of generalized models aimed at predicting water chemistry from otolith chemistry. Thus, the data presented here underscore the necessity of validation experiments to translate species-specific elemental signatures in otoliths.
\end{abstract}

KEY WORDS: Otolith chemistry · Salinity · Temperature · Strontium • Barium • Manganese • Magnesium · Lutjanus griseus

\section{INTRODUCTION}

For many fish species, adult populations are composed of juveniles recruiting from different habitats (e.g. coral reefs, seagrasses, mangrove prop roots) and environmental conditions (e.g. temperature, salinity, turbidity) (Beck et al. 2001). Specifically for reef fish, many species use a variety of non-reef habitats as juvenile nurseries (Chester \& Thayer 1990, Eggleston 1995, Ross \& Moser 1995, Dahlgren \& Eggleston 2000, Allman \& Grimes 2002). Although the effects of inhabiting different abiotic environments on feeding, growth, and metabolism of juveniles has been quantified in the lab for some reef fish species (Wuenschel et al. 2004, 2005), the effect of juvenile habitat and environment on ultimate survival and recruitment to adult populations remains uncertain for most reef fishes (Jones \& McCormick 2002, but see Gillanders \& Kingsford 1996).

Determining the elemental composition of otoliths is one approach for identifying the relative contribution of juveniles from different nursery habitats to adult populations (Gillanders \& Kingsford 1996, 2000, 
Rooker et al. 2001). Elemental signatures in fish otoliths can also be used to infer transport or migration pathways for individual fish (Secor 1992). Key assumptions underlying these applications are that fish incorporate elements from their environment and these elements are permanently deposited in their otoliths (Campana 1999).

While some studies have tested the effect of water temperature and salinity on element incorporation in otoliths (Farrell \& Campana 1996, Chesney et al. 1998, Bath et al. 2000, Milton \& Chenery 2001, Elsdon \& Gillanders 2002, 2004, Martin et al. 2004, Martin \& Thorrold 2005), the specific behavior of individual elements remains unclear. Elemental signatures in otoliths have been used successfully as natural tags in some species; however, important assumptions that influence the unambiguous use of these signatures have not been validated. For example, species-specific differences in elemental incorporation have not been evaluated in the laboratory under controlled conditions, and for most species the potential effect of differences in salinity or water temperature is unknown. Although understanding the details of elemental incorporation is not necessary for all applications of otolith elemental signatures, physical and biological factors can influence concentrations of these elements in the otolith, rendering the interpretation of elemental signatures more complex than assumed.

Gray snapper Lutjanus griseus, a reef fish whose juveniles use estuarine and near-shore habitats, can tolerate and grow over a wide range of temperatures and salinities (Wuenschel et al. 2004), making the species a good model for examining the effects of temperature and salinity on otolith element incorporation. Although previous experiments on gray snapper have demonstrated strong effects of temperature and salinity on feeding, growth, and metabolism (Wuenschel et al. 2004, 2005), the ultimate ecological consequences of inhabiting different nursery habitats and environments remains unclear. Elemental signatures in otoliths of gray snapper may provide a tool to evaluate the relative contribution of juveniles from different nursery habitats (sensu Gillanders \& Kingsford 1996). The goals of this study were to validate element incorporation in gray snapper L. griseus otoliths by quantifying the relation between otolith and water element concentrations ( $\mathrm{Sr} / \mathrm{Ca}, \mathrm{Mg} / \mathrm{Ca}, \mathrm{Mn} / \mathrm{Ca}$, and $\mathrm{Ba} / \mathrm{Ca}$ ) as a function of differences in water temperature and salinity.

\section{MATERIALS AND METHODS}

Gray snapper Lutjanus griseus were collected on a rising tide from the channel spanned by Pivers Island
Bridge, near Beaufort, North Carolina (USA), approximately $2 \mathrm{~km}$ inside of Beaufort Inlet. Larvae were collected using a $1 \times 2 \mathrm{~m}$ neuston net ( $1 \mathrm{~mm}$ mesh) with a floating live box attached to the cod end, fished at the surface (Hettler 1979). Sampling was conducted during nighttime maximum flood tides and concentrated around the days preceding full and new moons (Tzeng et al. 2003). Snapper were gently dipped from the live box and transferred to $100 \mathrm{l}$ holding tanks with flow-through seawater for temperature acclimation $\left(1^{\circ} \mathrm{C} \mathrm{d}^{-1}\right)$.

A fully crossed 2-way factorial design with equal replication was used to investigate the effects of 20 different temperature and salinity combinations on otolith element incorporation in juvenile gray snapper. A total of 5 tanks at each temperature and salinity combination were used (total $n=100,5$ replicates $\times 5$ salinities $\times 4$ temperatures). Temperature $(18,23$, 28 , and $33^{\circ} \mathrm{C}$ ) and salinity $(5,15,25,35$, and 45) levels were chosen to represent the range of environmental conditions experienced by gray snapper during the juvenile stage. Experiments were carried out in 2 trials due to limitations in laboratory space and availability of specimens. Owing to this constraint, a design was chosen that included all salinity levels within each trial. The first trial included the 28 and $33^{\circ} \mathrm{C}$ treatment temperatures and fish collected 5 to $6 \mathrm{~d}$ preceding the September new moon (1 to 5 September 2002). The second trial included the 18 and $23^{\circ} \mathrm{C}$ temperature treatments and the fish collected in the $5 \mathrm{~d}$ preceding the October new moon (30 September to 5 October 2002).

Individual gray snapper were stocked in experimental tanks (8 l) once the desired temperature treatment levels were attained. The 4 salinity levels were randomly assigned to the experimental tanks, and salinity in the experimental tanks was adjusted to $5 \mathrm{~d}^{-1}$ until the desired salinity treatment levels were reached. Salinity was maintained by mixing filtered seawater with either conditioned well water or Instant Ocean ${ }^{\circledR}$ synthetic sea salt. When all fish were at the desired treatment levels, they were acclimated for $1 \mathrm{wk}$ before the start of the $55 \mathrm{~d}$ experiment.

Snapper were fed several times daily, with diet changing from recently hatched Artemia nauplii to a prepared gel diet and live larval fish (Eucinostomus sp. or guppies) as fish grew throughout the experimental period. The same diets were offered to all fish within a given trial each day to reduce the effects (if any) of diet on otolith element incorporation. A one-third volume water change was performed daily to prevent the buildup of metabolic wastes and to maintain the desired salinity levels. Tank water temperatures and salinities were measured daily throughout the acclimation and experimental periods. 
Water samples. Water samples ( $\mathrm{n}=5$ per tank) were taken weekly for analysis of elemental water composition. Samples were collected using acid-washed $10 \mathrm{ml}$ polypropylene syringes and filtered through $0.2 \mu \mathrm{m}$ polypropylene syringe filters (Whatman) into $7 \mathrm{ml}$ acid-washed polypropylene vials. Each sample was acidified to $\mathrm{pH} 2$ with ultrapure $\mathrm{HCl}_{\text {conc }}$ and stored frozen until subsequent analyses.

Otolith analyses. At the conclusion of each experimental trial, all surviving fish were measured and their sagittal otolith pairs removed for otolith analyses. Otoliths were scraped clean with acid-washed glass probes in a class-100 clean room. Otoliths were ultrasonically cleaned in Milli-Q water for $7 \mathrm{~min}$ and triple rinsed with ultrapure $\mathrm{H}_{2} \mathrm{O}_{2}$ (Ultrex II, purchased from J. T. Baker) followed by 3 sequential rinses of Milli-Q water. Otoliths were then placed on acid-washed glass slides to dry for $36 \mathrm{~h}$ under a class-100 laminar-flow hood. After drying, otoliths were stored in acid-washed $1.5 \mathrm{ml}$ high-density polyethylene vials. The left otolith of each pair was mounted on a petrographic slide with superglue $^{\mathrm{TM}}$ and polished along the sagittal plane. After polishing, otoliths were soaked in Milli-Q water, cleaned, and dried as described above. Finally otoliths were mounted on petrographic slides (21 per slide) for high-resolution, inductively coupled plasma mass spectrometer (ICP-MS) analyses.

Because the fish for the 2 trials were live-captured at different times, they may have experienced different temperatures and salinities during the larval period. For that reason, laser ablation was used rather than whole otolith dissolution. The portion of the otolith was sampled that corresponded in time to the period during which fish were exposed to the experimental conditions (>30 d old). Curvilinear paths $(800 \mu \mathrm{m})$ along growth increments during the experimental period were plotted with the laser software and ablated on each otolith (Fig. 1) using a New Wave UP-213 laser with a $40 \mu \mathrm{m}$ beam width coupled to a Thermo Finnigan Element ICP-MS equipped with a self-aspirating $\left(50 \mu \mathrm{min}^{-1}\right)$ PFA nebulizer (Elemental Scientific, Inc. [ESI]) and a dual-inlet quartz spray chamber. The method measured ${ }^{25} \mathrm{Mg},{ }^{48} \mathrm{Ca},{ }^{55} \mathrm{Mn},{ }^{86} \mathrm{Sr}$, and ${ }^{138} \mathrm{Ba}$ in low resolution $(\mathrm{R}=300)$ during a 2 min acquisition time.

Quantification of metal/calcium (Me/Ca) ratios followed the procedure outlined by Rosenthal et al. (1999). All samples were standardized to a dissolved solution $\left(0.1 \mathrm{mg} \mathrm{g}^{-1}\right)$ of an otolith reference powder with certified $\mathrm{Me} / \mathrm{Ca}$ ratios of $89.25 \mu \mathrm{mol} \mathrm{mol} \mathrm{m}^{-1}$ for $\mathrm{Mg} / \mathrm{Ca}, 0.257 \mu \mathrm{mol} \mathrm{mol}{ }^{-1}$ for $\mathrm{Mn} / \mathrm{Ca}, 2.782 \mu \mathrm{mol} \mathrm{mol}^{-1}$ for $\mathrm{Sr} / \mathrm{Ca}$, and $2.174 \mu \mathrm{mol} \mathrm{mol}{ }^{-1}$ for $\mathrm{Ba} / \mathrm{Ca}$ (Yoshinaga et al. 2000). The matrix of the standard was therefore matched to the Ca levels in the samples. Detection limits were calculated as $3 \sigma$ values of $1 \% \mathrm{HNO}_{3}$ sample

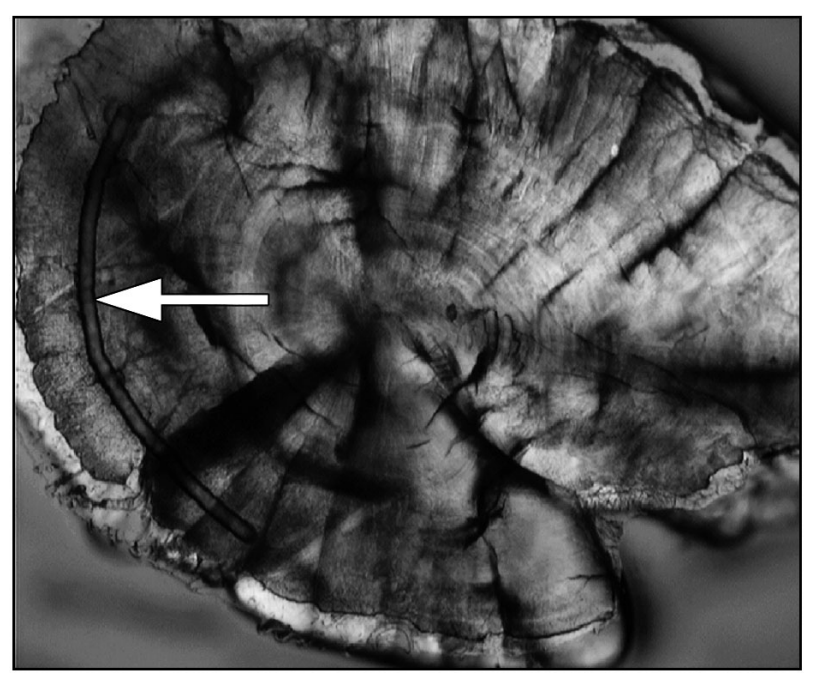

Fig. 1. Lutjanus griseus. Sagittal otolith polished in the sagittal plane showing the laser scar (arrow) resulting from sampling of growth increments deposited during the experiment

blanks $(\mathrm{n}=18)$ that were run throughout the analyses. These limits were $1.5 \%$ of the average sample intensity for ${ }^{25} \mathrm{Mg}, 0.1 \%$ for ${ }^{48} \mathrm{Ca}, 21 \%$ for ${ }^{55} \mathrm{Mn}, 0.04 \%$ for ${ }^{86} \mathrm{Sr}$, and $0.2 \%$ for ${ }^{138} \mathrm{Ba}$. An internal laboratory standard was run after each reference sample to estimate precision of the $\mathrm{Me} / \mathrm{Ca}$ method. The reference material was then treated as an unknown and Me/Ca values determined as for individual samples above. Measured precision ( $\%$ relative standard deviation [RSD], $\mathrm{n}=18$ ) of the $\mathrm{Me} / \mathrm{Ca}$ method was $0.3 \%$ for $\mathrm{Mg} / \mathrm{Ca}, 1.2 \%$ for $\mathrm{Mn} / \mathrm{Ca}, 0.4 \%$ for $\mathrm{Sr} / \mathrm{Ca}$, and $0.4 \%$ for $\mathrm{Ba} / \mathrm{Ca}$.

Water analyses. Analyses of water samples collected during the experiment were conducted using ICP-MS. Water samples were run from each tank representing the average conditions over the course of the experiment. All samples were spiked with indium (to $4.5 \mu \mathrm{g}$ $\mathrm{g}^{-1}$ ), which was used as an internal standard. The solutions were then aspirated into a Thermo Finnigan Element 2 ICP-MS, via a self-aspirating nebulizer

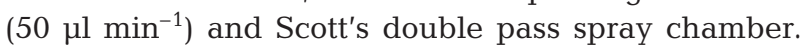
Due to the presence of significant interferences on most of the Ca isotopes, ${ }^{44} \mathrm{Ca},{ }^{88} \mathrm{Sr}{ }^{25} \mathrm{Mg},{ }^{55} \mathrm{Mn},{ }^{137} \mathrm{Ba}$, and ${ }^{115} \mathrm{In}$ were measured in medium resolution (nominal $R=4500$ ). A total of 3 of the 5 weekly samples from each tank were analyzed and the mean values were then used in all subsequent analyses. To estimate precision of the water measurements, $\mathrm{Ca}, \mathrm{Sr}, \mathrm{Mg}, \mathrm{Mn}$, and Ba values in a seawater Certified Reference Material (CRM), (High Purity Standards, Inc.) were determined. The estimates of precision for element concentrations in the seawater CRM for Trial 1 were $2.1 \% \mathrm{RSD}$ for $\mathrm{Ca}$, $4.2 \% \mathrm{RSD}$ for $\mathrm{Sr}, 1.7 \% \mathrm{RSD}$ for $\mathrm{Mg}, 12.2 \% \mathrm{RSD}$ for $\mathrm{Mn}$, and $4.5 \%$ RSD for Ba $(\mathrm{n}=3)$ and Trial 2 were $1.4 \%$ RSD for $\mathrm{Ca}, 1.3 \% \mathrm{RSD}$ for $\mathrm{Sr}, 1.3 \% \mathrm{RSD}$ for $\mathrm{Mg}, 6.8 \% \mathrm{RSD}$ 
for $\mathrm{Mn}$, and $3.9 \%$ RSD for Ba $(\mathrm{n}=3)$. Partition coefficients $\left(D_{\mathrm{Me}}\right)$ were calculated by dividing the metal/ calcium $(\mathrm{Me} / \mathrm{Ca})$ ratio measured in an otolith by the mean $\mathrm{Me} / \mathrm{Ca}$ ratio measured in the treatment tank water (Morse \& Bender 1990).

Statistical analyses. Two-way analysis of variance (ANOVA) was used to test for significant differences in $[\mathrm{Me} / \mathrm{Ca}]_{\text {water, }}[\mathrm{Me} / \mathrm{Ca}]_{\text {otolith, }}$ and $D_{\mathrm{Me}}$ among temperature and salinity treatments. Because different cohorts of fish and temperatures were used in the 2 trials, a separate ANOVA was performed for each trial (Bonferroni corrected $\alpha=0.0125)$. Salinity and temperature were treated as independent categorical variables, and $[\mathrm{Me} / \mathrm{Ca}]_{\text {water, }}[\mathrm{Me} / \mathrm{Ca}]_{\text {otolith, }}$ and $D_{\mathrm{Me}}$ as dependent variables in the analyses. $[\mathrm{Me} / \mathrm{Ca}]_{\text {otolith }}$ data were logtransformed to reduce heteroscedasticity, lessening the magnitude of differences among treatment groups. The data transformations did not make all of the variances homogeneous, but considering the $F$ statistic is robust despite differences in sample variances (Lindman 1974), we feel confident in the subsequent ANOVAs. Because $D_{\mathrm{Me}}$ are proportions, data were arcsin-transformed (Zar 1999).

\section{RESULTS}

The means and ranges of $[\mathrm{Me} / \mathrm{Ca}]_{\text {otoliths }}$ and $D_{\mathrm{Me}}$ from 90 (Trial 1: $\mathrm{n}=45$, Trial 2: $\mathrm{n}=45$ ) juvenile Lutjanus griseus and the tank $[\mathrm{Me} / \mathrm{Ca}]_{\text {water }}(\mathrm{n}=90)$ are reported in Table 1. Survival of reared L. griseus was high $(90 \%)$ over the range of experimental treatment combinations, and the few mortalities (10 out of 100) were not related to temperature or salinity over this range, as in other studies (Wuenschel et al. 2004, 2005).

\section{Water chemistry}

$[\mathrm{Me} / \mathrm{Ca}]_{\text {water }}$ values were variable for each element analyzed (Table 1). As expected, elemental concentrations in the tank water were significantly affected by salinity treatments for both trials, but not temperature (Table 2).
Table 2. Results of 4 separate 2-way ANOVA for each trial testing the effect of temperature (T) and salinity (S) on 4 elemental concentrations in the individual tank water $(\mathrm{n}=45$ for each elemental ratio). ${ }^{*}$ Significant at $\alpha=0.0125$

\begin{tabular}{|c|c|c|c|c|c|}
\hline & Factor & $\mathrm{df}$ & MS & $F$ & $\mathrm{p}$ \\
\hline $\begin{array}{l}\text { Trial } 1 \\
{[\mathrm{Sr} / \mathrm{Ca}]_{\text {water }}}\end{array}$ & $\begin{array}{c}\mathrm{T} \\
\mathrm{S} \\
\mathrm{T} \times \mathrm{S} \\
\text { Error }\end{array}$ & $\begin{array}{c}1 \\
4 \\
4 \\
35\end{array}$ & $\begin{array}{l}0.030 \\
6.331 \\
0.173 \\
0.096\end{array}$ & $\begin{array}{c}0.311 \\
66.160 \\
1.812\end{array}$ & $\begin{array}{c}0.581 \\
<0.001^{*} \\
0.148\end{array}$ \\
\hline$[\mathrm{Mg} / \mathrm{Ca}]_{\text {water }}$ & $\begin{array}{c}\mathrm{T} \\
\mathrm{S} \\
\mathrm{T} \times \mathrm{S} \\
\text { Error }\end{array}$ & $\begin{array}{c}1 \\
4 \\
4 \\
35\end{array}$ & $\begin{array}{l}0.001 \\
5.373 \\
0.117 \\
0.032\end{array}$ & $\begin{array}{c}0.016 \\
166.829 \\
3.642\end{array}$ & $\begin{array}{c}0.899 \\
<0.001^{*} \\
0.014\end{array}$ \\
\hline$[\mathrm{Mn} / \mathrm{Ca}]_{\text {water }}$ & $\begin{array}{c}\mathrm{T} \\
\mathrm{S} \\
\mathrm{T} \times \mathrm{S} \\
\text { Error }\end{array}$ & $\begin{array}{c}1 \\
4 \\
4 \\
35\end{array}$ & $\begin{array}{c}273.448 \\
1389.692 \\
41.657 \\
521.713\end{array}$ & $\begin{array}{l}0.524 \\
2.664 \\
0.080\end{array}$ & $\begin{array}{l}0.474 \\
0.049 \\
0.988\end{array}$ \\
\hline$[\mathrm{Ba} / \mathrm{Ca}]_{\text {water }}$ & $\begin{array}{c}\mathrm{T} \\
\mathrm{S} \\
\mathrm{T} \times \mathrm{S} \\
\text { Error }\end{array}$ & $\begin{array}{c}1 \\
4 \\
4 \\
35\end{array}$ & $\begin{array}{c}0.180 \\
42.094 \\
0.437 \\
0.895\end{array}$ & $\begin{array}{c}0.202 \\
47.049 \\
0.488\end{array}$ & $\begin{array}{c}0.656 \\
<0.001^{*} \\
0.744\end{array}$ \\
\hline $\begin{array}{l}\text { Trial } 2 \\
{[\mathrm{Sr} / \mathrm{Ca}]_{\text {water }}}\end{array}$ & $\begin{array}{c}\mathrm{T} \\
\mathrm{S} \\
\mathrm{T} \times \mathrm{S} \\
\text { Error }\end{array}$ & $\begin{array}{c}1 \\
4 \\
4 \\
35\end{array}$ & $\begin{array}{l}0.076 \\
1.820 \\
0.182 \\
0.273\end{array}$ & $\begin{array}{l}0.279 \\
6.670 \\
0.667\end{array}$ & $\begin{array}{c}0.601 \\
<0.001^{*} \\
0.619\end{array}$ \\
\hline$[\mathrm{Mg} / \mathrm{Ca}]_{\text {water }}$ & $\begin{array}{c}\mathrm{T} \\
\mathrm{S} \\
\mathrm{T} \times \mathrm{S} \\
\text { Error }\end{array}$ & $\begin{array}{c}1 \\
4 \\
4 \\
35\end{array}$ & $\begin{array}{l}0.007 \\
4.375 \\
0.003 \\
0.013\end{array}$ & $\begin{array}{c}0.502 \\
332.576 \\
0.258\end{array}$ & $\begin{array}{c}0.483 \\
<0.001^{*} \\
0.903\end{array}$ \\
\hline$[\mathrm{Mn} / \mathrm{Ca}]_{\text {water }}$ & $\begin{array}{c}\mathrm{T} \\
\mathrm{S} \\
\mathrm{T} \times \mathrm{S} \\
\text { Error }\end{array}$ & $\begin{array}{c}1 \\
4 \\
4 \\
35\end{array}$ & $\begin{array}{c}8.450 \\
424.147 \\
329.923 \\
138.653\end{array}$ & $\begin{array}{l}0.061 \\
3.059 \\
2.379\end{array}$ & $\begin{array}{l}0.806 \\
0.029 \\
0.070\end{array}$ \\
\hline$[\mathrm{Ba} / \mathrm{Ca}]_{\text {water }}$ & $\begin{array}{c}\mathrm{T} \\
\mathrm{S} \\
\mathrm{T} \times \mathrm{S} \\
\text { Error }\end{array}$ & $\begin{array}{c}1 \\
4 \\
4 \\
35\end{array}$ & $\begin{array}{c}0.374 \\
54.381 \\
1.833 \\
1.390\end{array}$ & $\begin{array}{c}0.269 \\
39.131 \\
1.319\end{array}$ & $\begin{array}{c}0.607 \\
<0.001^{*} \\
0.282\end{array}$ \\
\hline
\end{tabular}

\section{Otolith [Me/Ca]}

$[\mathrm{Me} / \mathrm{Ca}]_{\text {otoliths }}$ were also variable for each element analyzed (Table 1). Temperature (Trial 2) and salinity (Trial 1) had significant effects on $[\mathrm{Sr} / \mathrm{Ca}]_{\text {otolith }}$ for Lutjanus griseus without a significant interaction effect

Table 1. Lutjanus griseus. Combined trial means and ranges for each metal/calcium $[\mathrm{Me} / \mathrm{Ca}]_{\text {otolith }}(\mathrm{n}=90),[\mathrm{Me} / \mathrm{Ca}]_{\mathrm{water}}(\mathrm{n}=90)$, and the partition coefficient of metals $D_{\mathrm{Me}}(\mathrm{n}=90)$. $[\mathrm{Mg} / \mathrm{Ca}]_{\mathrm{water}}$ values are $\mathrm{mol} \mathrm{mol}^{-1}$. $[\mathrm{Sr} / \mathrm{Ca}]_{\text {otolith, }}[\mathrm{Sr} / \mathrm{Ca}]_{\mathrm{water}}$ and $[\mathrm{Mg} / \mathrm{Ca}]_{\text {otolith }}$ values are $\mathrm{mmol} \mathrm{mol}^{-1},[\mathrm{Mn} / \mathrm{Ca}]_{\text {otolithr }}[\mathrm{Mn} / \mathrm{Ca}]_{\text {water, }}[\mathrm{Ba} / \mathrm{Ca}]_{\text {otolith }}$ and $[\mathrm{Ba} / \mathrm{Ca}]_{\text {water }}$ values are $\mu \mathrm{mol} \mathrm{mol}^{-1}$

\begin{tabular}{|llcccccccc}
\hline Parameter & Mean & Range & Parameter & Mean & Range & Parameter & Mean & Range \\
\hline$[\mathrm{Sr} / \mathrm{Ca}]_{\text {otolith }}$ & 2.27 & $1.72-2.88$ & {$[\mathrm{Sr} / \mathrm{Ca}]_{\text {water }}$} & 7.97 & $6.52-9.86$ & $D_{\mathrm{Sr}}$ & 0.287 & $0.211-0.380$ \\
{$[\mathrm{Mg} / \mathrm{Ca}]_{\text {otolith }}$} & 0.088 & $0.036-0.247$ & {$[\mathrm{Mg} / \mathrm{Ca}]_{\text {water }}$} & 4.17 & $2.65-5.35$ & $D_{\mathrm{Mg}}$ & $2.19 \times 10^{-5}$ & $7.65 \times 10^{-6}-8.91 \times 10^{-5}$ \\
{$[\mathrm{Mn} / \mathrm{Ca}]_{\text {otolith }}$} & 8.22 & $1.38-29.36$ & {$[\mathrm{Mn} / \mathrm{Ca}]_{\text {water }}$} & 36.16 & $13.49-117.94$ & $D_{\mathrm{Mn}}$ & 0.285 & $0.0176-1.02$ \\
{$[\mathrm{Ba} / \mathrm{Ca}]_{\text {otolith }}$} & 1.24 & $0.491-3.12$ & {$[\mathrm{Ba} / \mathrm{Ca}]_{\text {water }}$} & 10.21 & $4.31-15.28$ & $D_{\mathrm{Ba}}$ & 0.13 & $0.044-0.45$ \\
\hline
\end{tabular}


(Table 3, Fig. 2). Neither temperature, salinity, nor the interaction of the 2 had a significant effect on $[\mathrm{Mg} / \mathrm{Ca}]_{\text {otolith }}$ or $[\mathrm{Mn} / \mathrm{Ca}]_{\text {otolith }}$ (Table 3, Fig. 3). There was a significant salinity effect (Trial 1) but no significant temperature effect on $[\mathrm{Ba} / \mathrm{Ca}]_{\text {otolith }}$ (Table 3, Fig. 3), and the interaction between the 2 factors was not significant.

\section{Me/Ca partition coefficients}

Temperature (Trial 2) and salinity (Trial 1) had significant effects on $D_{\mathrm{Sr}}$, with no interaction between the 2 factors (Table 4, Fig. 4). The effect of temperature was significant at the lower temperatures treatments (18 and $23^{\circ} \mathrm{C}$ ), and the effect of salinity was significant only at the higher temperature treatments (28 and $33^{\circ} \mathrm{C}$ ). The effects of temperature, salinity, and the temperature-salinity interaction on $D_{\mathrm{Mg}}$ and $D_{\mathrm{Mn}}$ were not significant (Table 4, Fig. 4). Salinity had a significant effect on $D_{\text {Ba }}$ in both trials, with a non-significant temperature effect and a non-significant interaction between the 2 factors (Table 4, Fig. 4).

\section{DISCUSSION}

For a given species, otolith element incorporation is not solely a function of water elemental composition because it is uniquely influenced by temperature and salinity for each element investigated. Application of otolith elemental signatures to determine nursery habitats assumes that differences observed in otolith chemistry reflect differences in the water chemistry of various nursery habitats. The realization that otolith element incorporation can be influenced by abiotic (temperature and salinity) and biotic (growth rate and diet) factors indicates the need to quantify the relative importance of these effects for individual species and elements. The relative magnitude of these effects (which may be statistically significant) may not result in misclassification of individuals; however, it may prove useful in explaining variation in specific elements and determine the precision of inferring environmental histories. The main objective of this experiment was to determine the effect of temperature and salinity on element incorporation in the otoliths of juvenile gray snapper to assess the usefulness of otolith element signatures for inferring life history information such as nursery habitat use for this species. The broad range of temperatures and salinities used in the present study encompass those occupied by juveniles Lutjanus griseus in the wild (Starck \& Schroeder 1970, Chester \& Thayer 1990, Nagelkerken et al. 2000) and there-
Table 3. Lutjanus griseus. Results of 4 separate 2-way ANOVA for each trial testing the effect of temperature (T) and salinity (S) on 4 elemental signatures (log-transformed) in the otoliths of juvenile gray snapper * Significant at $\alpha=0.0125$

\begin{tabular}{|c|c|c|c|c|c|}
\hline & Factor & $\mathrm{df}$ & MS & $F$ & $\mathrm{p}$ \\
\hline \multicolumn{6}{|l|}{ Trial 1} \\
\hline \multirow{2}{*}[\mathrm{Sr}/\mathrm{Ca}]{$_{\text {otolith }}$} & $\mathrm{S}$ & 4 & 0.010 & 6.666 & $<0.001^{*}$ \\
\hline & $\mathrm{T} \times \mathrm{S}$ & 4 & 0.004 & 2.844 & 0.038 \\
\hline \multirow[t]{3}{*}[\mathrm{Mg}/\mathrm{Ca}]{$_{\text {otolith }}$} & $\mathrm{T}$ & 1 & 0.035 & 0.917 & 0.345 \\
\hline & S & 4 & 0.012 & 0.316 & 0.866 \\
\hline & $\mathrm{T} \times \mathrm{S}$ & 4 & 0.035 & 0.938 & 0.454 \\
\hline \multirow[t]{3}{*}[\mathrm{Mn}/\mathrm{Ca}]{$_{\text {otolith }}$} & $\mathrm{T}$ & 1 & 0.007 & 0.064 & 0.802 \\
\hline & S & 4 & 0.093 & 0.886 & 0.483 \\
\hline & $\mathrm{T} \times \mathrm{S}$ & 4 & 0.117 & 1.108 & 0.368 \\
\hline \multirow{3}{*}[\mathrm{Ba}/\mathrm{Ca}]{$_{\text {otolith }}$} & $\mathrm{T}$ & 1 & 0.014 & 0.651 & 0.425 \\
\hline & $\mathrm{S}$ & 4 & 0.087 & 4.033 & $0.009^{*}$ \\
\hline & $\mathrm{T} \times \mathrm{S}$ & 4 & 0.020 & 0.939 & 0.453 \\
\hline \multicolumn{6}{|l|}{ Trial 2} \\
\hline \multirow[t]{3}{*}[\mathrm{Sr}/\mathrm{Ca}]{$_{\text {otolith }}$} & $\mathrm{T}$ & 1 & 0.020 & 10.146 & $0.003^{*}$ \\
\hline & S & 4 & 0.003 & 1.509 & 0.221 \\
\hline & $\mathrm{T} \times \mathrm{S}$ & 4 & 0.003 & 1.515 & 0.219 \\
\hline \multirow[t]{3}{*}[\mathrm{Mg}/\mathrm{Ca}]{$_{\text {otolith }}$} & $\mathrm{T}$ & 1 & 0.019 & 0.459 & 0.502 \\
\hline & S & 4 & 0.044 & 1.065 & 0.388 \\
\hline & $\mathrm{T} \times \mathrm{S}$ & 4 & 0.037 & 0.882 & 0.485 \\
\hline \multirow[t]{3}{*}[\mathrm{Mn}/\mathrm{Ca}]{$_{\text {otolith }}$} & $\mathrm{T}$ & 1 & 0.031 & 0.429 & 0.517 \\
\hline & S & 4 & 0.037 & 0.520 & 0.721 \\
\hline & $\mathrm{T} \times \mathrm{S}$ & 4 & 0.105 & 1.458 & 0.236 \\
\hline \multirow[t]{3}{*}[\mathrm{Ba}/\mathrm{Ca}]{$_{\text {otolith }}$} & $\mathrm{T}$ & 1 & 0.004 & 0.118 & 0.734 \\
\hline & S & 4 & 0.037 & 1.009 & 0.416 \\
\hline & $\mathrm{T} \times \mathrm{S}$ & 4 & 0.041 & 1.098 & 0.373 \\
\hline
\end{tabular}

fore provide a realistic test for using otolith chemistry to infer environmental history of individuals.

Few laboratory-based validation experiments have been used to address otolith element incorporation for different species. One of the only other laboratory experiments to address the effect of temperature and salinity on $\mathrm{Sr} / \mathrm{Ca}, \mathrm{Mg} / \mathrm{Ca}, \mathrm{Mn} / \mathrm{Ca}$, and $\mathrm{Ba} / \mathrm{Ca}$ incorporation in otoliths (Elsdon \& Gillanders 2002) used both single-factor and 2-factor designs. They found significant temperature and salinity interaction effects on all 4 $\mathrm{Me} / \mathrm{Ca}$ ratios in juvenile black bream Acanthopagurus butcheri. If the assumption that otolith element incorporation is proportional to the water elemental composition is correct, then the most appropriate way to discern interspecies differences would be to compare partition coefficients. Elsdon \& Gillanders (2002) did not calculate partition coefficients, but best estimates of the ranges (for 12 to $24^{\circ} \mathrm{C}$ and 5 to 30 salinity) made by inspection of their graphs and water data table are reported in Table 5 for $D_{\mathrm{Sr}}, D_{\mathrm{Mg}}, D_{\mathrm{Mn}}$, and $D_{\mathrm{Ba}}$. Using the results from this study for Lutjanus griseus (for 18 to $33^{\circ} \mathrm{C}$ and 5 to 45 salinity) and that of Martin et al. (2004) and Martin \& Thorrold (2005) for Leiostomus xanthurus 


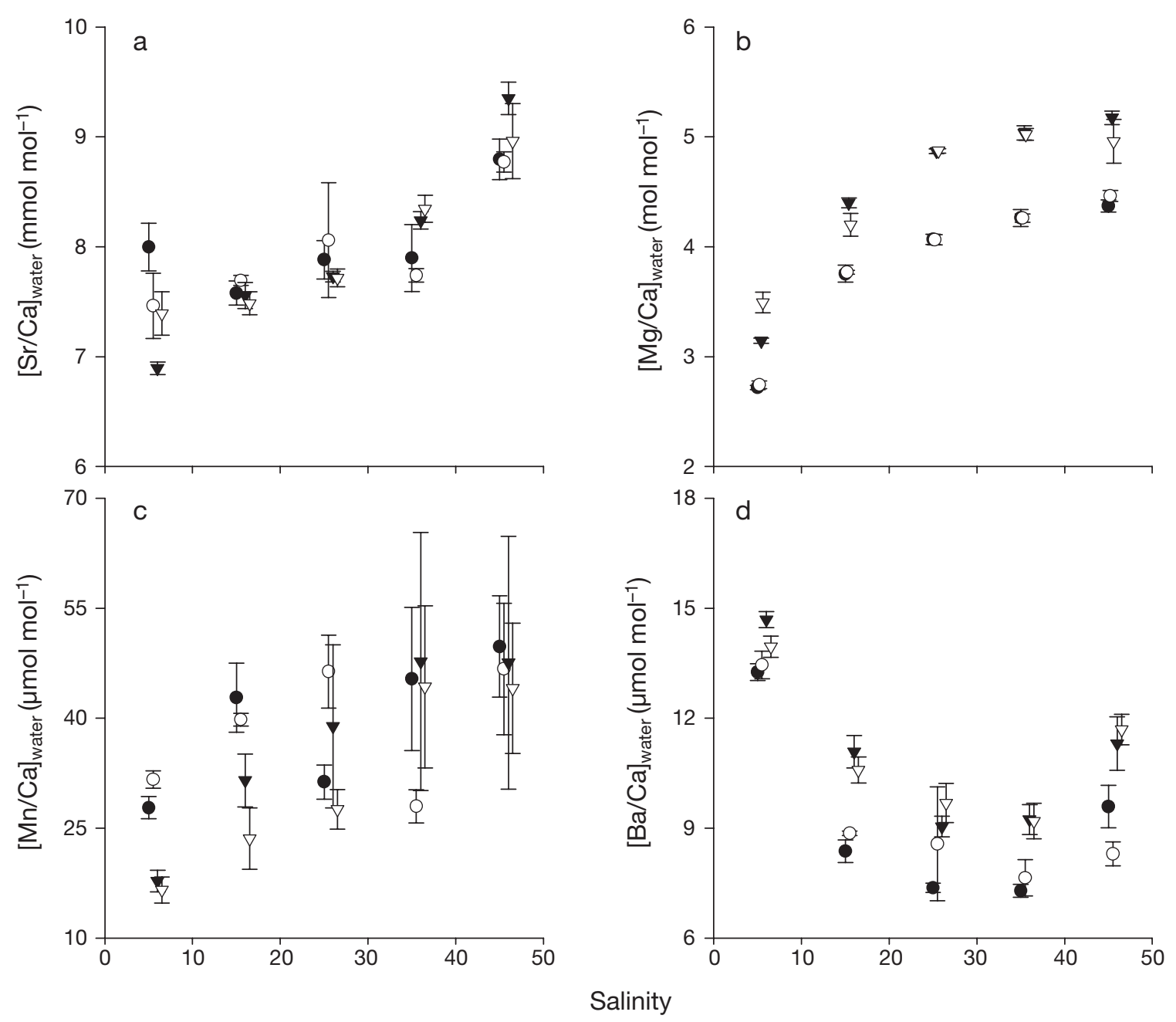

Fig. 2. Calculated metal/calcium ratios in the tank water for both trials: (a) Sr/Ca, (b) $\mathrm{Mg} / \mathrm{Ca}$, (c) Mn/Ca, and (d) Ba/Ca concentrations $\pm 1 \mathrm{SE}$ by salinity treatment. Each of the 4 temperature treatments is represented by a different symbol: $18(\boldsymbol{\bullet}), 23(\mathrm{O}), 28(\boldsymbol{\nabla})$, and $33(\nabla)^{\circ} \mathrm{C}$. Data markers are offset so that all error bars and symbols can be seen clearly

(for 17 to $26^{\circ} \mathrm{C}$ and 15 to 25 salinity), the $D_{\mathrm{Sr}}$ values for $A$. butcheri were higher than the values for both $L$. xanthurus and L. griseus. Whereas the $D_{\mathrm{Mn}}$ values for $A$. butcheri were similar to $L$. xanthurus and only slightly higher than $L$. griseus, $D_{\mathrm{Mg}}$ values were similar between $A$. butcheri and L. xanthurus but were 1 order of magnitude greater than those calculated for $L$. griseus. Similarly, $D_{\mathrm{Ba}}$ ranges were the same for $A$. butcheri and L. xanthurus but higher than $D_{\mathrm{Ba}}$ in L. griseus. Differences in ontogeny do not explain the varied results of temperature and salinity effects on otolith element incorporation because the experiments were conducted with fish at the same life stage (late larval-early juvenile). Diets fed to fish for each experiment were different, which may explain some of the variability in relative $[\mathrm{Me} / \mathrm{Ca}]_{\text {otolith }}$ values, although experimental studies have found little evidence for an effect of diet on otolith element incorporation (Hoff \& Fuiman 1995, Milton \& Chenery 2001, Walther \& Thorrold 2006, but see Buckel et al. 2004). These discrepancies highlight the potential for species-specific element incorporation. Mechanisms controlling the uptake of individual elements into the otolith matrices differentially influence the partition coefficients.

Species may be different with regard to otolith chemistry because they have different environmental tolerances and employ different methods to maintain hydromineral balance. The present study investigated a wider range in salinity than previous studies (see Elsdon \& Gillanders 2003 for review), which were both below and above the average isosmotic salinity for marine teleost fishes ( 10 to 15; Karnaky 1998). Euryhaline fishes employ different extrarenal epithelial tissues (including the gills, integument, gut, and bladder) to 

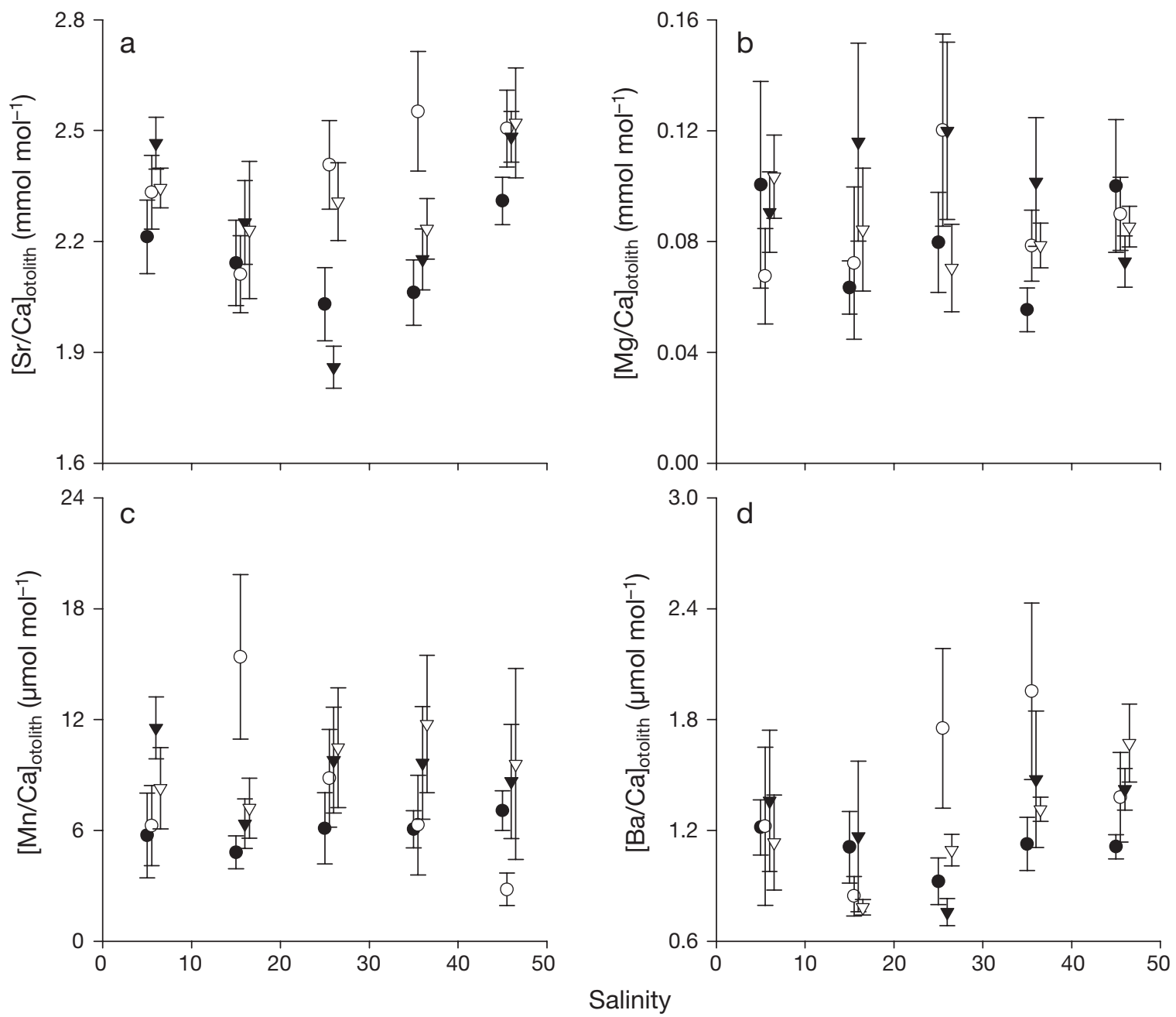

Fig. 3. Lutjanus griseus. Mean (a) $\mathrm{Sr} / \mathrm{Ca}$, (b) $\mathrm{Mg} / \mathrm{Ca}$, (c) $\mathrm{Mn} / \mathrm{Ca}$, and (d) $\mathrm{Ba} / \mathrm{Ca} \pm 1 \mathrm{SE}$ in otoliths of L. griseus for both trials as a function of salinity at tank temperatures $18(\mathbf{O}), 23(\mathrm{O}), 28(\boldsymbol{\nabla})$, and $33(\nabla)^{\circ} \mathrm{C}$. Data markers are offset so that all error bars and symbols can be seen clearly

achieve osmoregulation depending on whether they are above or below the isosmotic salinity. Ionic balance may be achieved through a combination of passive and active transport. Therefore the pathways and potential barriers between the external environment and the fish are not constant over this range in salinity, which may confound the relationship between element concentrations in the external environment and otolith. Thus, in addition to being species and element specific, $D_{\mathrm{Me}}$ relationships for euryhaline fishes are likely to be different in hyposmotic versus hyperosmotic environments.

Somatic growth rate and otolith precipitation rate may also influence element incorporation, as demonstrated for $[\mathrm{Mg} / \mathrm{Ca}]_{\text {otolith }}$ in Lutjanus xanthurus (Martin $\&$ Thorrold 2005). It is well documented that slower growing fish have proportionately heavier otoliths (Reznick et al. 1989, Secor \& Dean 1989, Pawson 1990,
Worthington et al. 1995); therefore, growth rate can influence both the amount and relative proportion of elements incorporated in the matrix. Thus, somatic growth rate may act to modify the relative importance of water chemistry, diet, temperature and salinity, and internal physiology on otolith element incorporation. The effect of somatic growth rate on element incorporation may be particularly important for larval and juvenile fishes that exhibit higher (and more variable) growth rates compared to later life stages. The ad libitum feeding condition and wide range of temperatures in the present study resulted in a wide range of growth rates, largely determined by temperature, thus precluding a test of growth rate effects. To determine the effect of growth rate on element incorporation, an experimental design with various feeding (growth) rates within each temperature and salinity combina- 

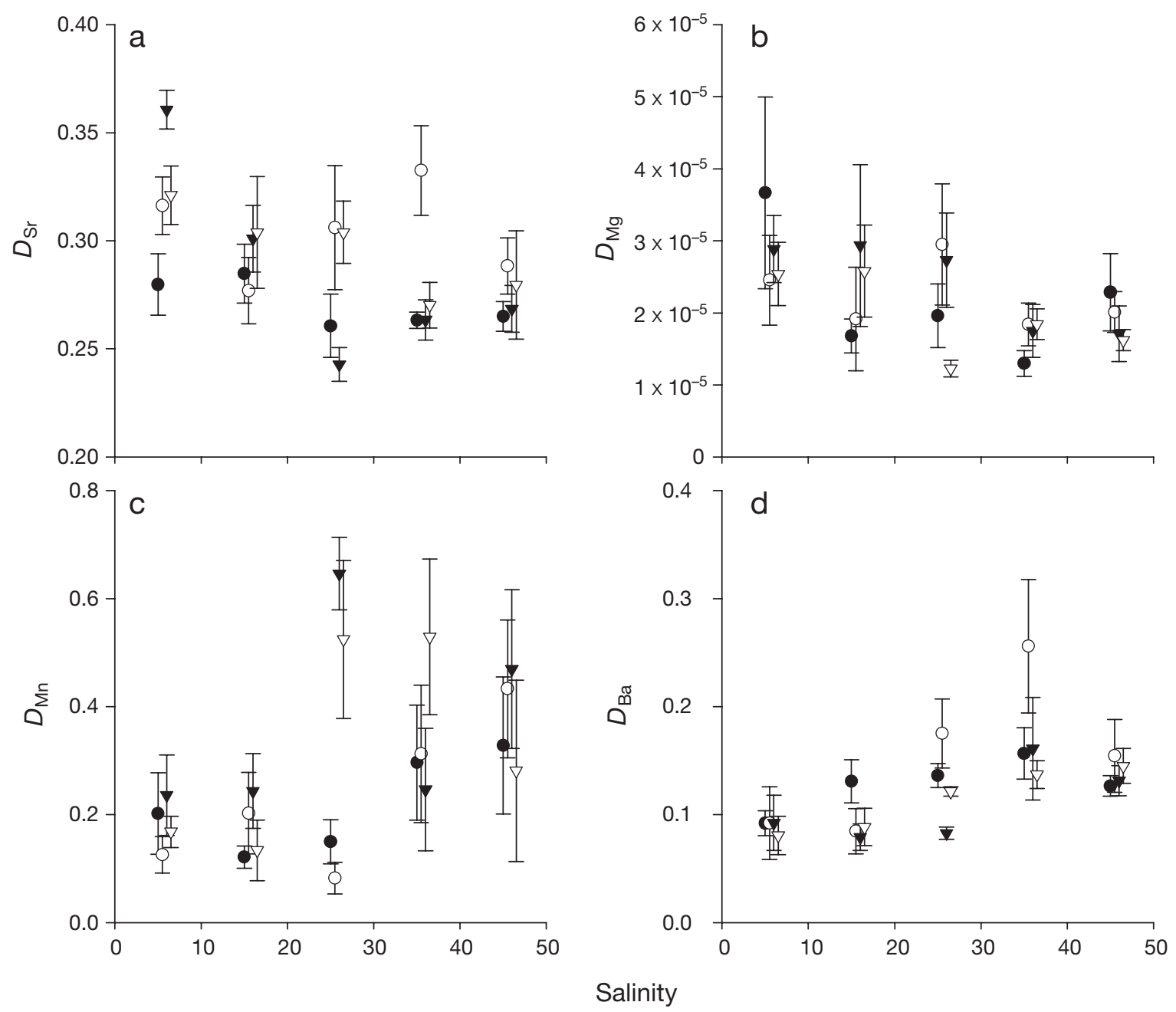

Fig. 4. Lutjanus griseus. Mean partition coefficients (a) Sr/Ca $\left(D_{\mathrm{Sr}}\right)$, (b) $\mathrm{Mg} / \mathrm{Ca}\left(D_{\mathrm{Mg}}\right)$, (c) $\mathrm{Mn} / \mathrm{Ca}\left(D_{\mathrm{Mn}}\right)$, and $(\mathrm{d}) \mathrm{Ba} / \mathrm{Ca}\left(D_{\mathrm{Ba}}\right)$ for otoliths of L. griseus for both trials as a function of salinity at tank temperatures $18(\boldsymbol{O}), 23(\mathrm{O}), 28(\boldsymbol{\nabla})$, and $33(\nabla)^{\circ} \mathrm{C}$. Data markers are offset so that all error bars and symbols can be seen clearly

tion would be necessary. The influence of growth rate on otolith element incorporation may be obscured in gray snapper, which have been shown to alter their energetics (feeding rate, gross conversion efficiency, and metabolism; Wuenschel et al. 2004, 2005) in relation to salinity, yet salinity had little effect on growth. Subtle changes in the energetics of gray snapper in response to salinity affect the proportion of consumption that is translated to somatic growth. It remains uncertain how changes in gross conversion efficiency affect the influence of diet on otolith element incorporation. Likewise, changes in metabolism may require more (or less) water to come in contact with gills for gas exchange and thereby affect the influence of water chemistry on otolith element incorporation.

Species-specific differences in element incorporation in otoliths make it difficult to generalize results among taxa, but perhaps of greater importance to studies using these techniques are the marked differences in element incorporation attributable to changes in temperature and salinity. For example, studies on eels (Tzeng et al. 1997, Jessop et al. 2002, Daverat et al. 2006), American shad (Limburg 2001) and striped bass (Secor 1992, Secor et al. 1995) have used $[\mathrm{Sr} / \mathrm{Ca}]_{\text {otolith }}$ as proxies for salinity changes in the water. These studies interpreted fish migration paths based primarily on salinity differences from $\mathrm{Sr} / \mathrm{Ca}$ signatures in the otoliths. However, conclusions about fish migrations based on the $[\mathrm{Sr} / \mathrm{Ca}]_{\text {otolith}}$-salinity relationship are potentially confounded by the effect of temperature on [Sr/Ca $]_{\text {otolith }}$ incorporation. The magnitude of change in $[\mathrm{Sr} / \mathrm{Ca}]_{\text {otolith }}$ observed in the present study, due to temperature and salinity (1.72 to 2.88$)$ is much less than the range in values generally used to infer migration in previous studies, which was 0 to 10 for eels (Daverat et al. 2006), 0 to 3 in American shad 
Table 4. Lutjanus griseus. Results of 4 separate 2-way ANOVA for both trials testing the effect of temperature (T) and salinity (S) on 4 partition coefficients $D$ (arcsintransformed) in the otoliths of juvenile gray snapper ${ }^{*}$ Significant at $\alpha=0.0125$. Trial $1: 28-33^{\circ} \mathrm{C}$, Trial $2: 18-23^{\circ} \mathrm{C}$

\begin{tabular}{|c|c|c|c|c|c|}
\hline & Factor & df & MS & $F$ & $\mathrm{p}$ \\
\hline \multicolumn{6}{|c|}{ Trial 1} \\
\hline \multirow[t]{3}{*}{$D_{\mathrm{Sr}}$} & $\mathrm{T}$ & 1 & 0.002 & 1.345 & 0.254 \\
\hline & $\mathrm{S}$ & 4 & 0.011 & 9.352 & $<0.001^{*}$ \\
\hline & $\mathrm{T} \times \mathrm{S}$ & 4 & 0.004 & 3.163 & 0.025 \\
\hline \multirow[t]{3}{*}{$D_{\mathrm{Mg}}$} & $\mathrm{T}$ & 1 & 0.000 & 1.417 & 0.242 \\
\hline & $\mathrm{S}$ & 4 & 0.000 & 2.992 & 0.032 \\
\hline & $\mathrm{T} \times \mathrm{S}$ & 4 & 0.000 & 0.749 & 0.565 \\
\hline \multirow[t]{3}{*}{$D_{\mathrm{Mn}}$} & $\mathrm{T}$ & 1 & 0.006 & 0.068 & 0.796 \\
\hline & $\mathrm{S}$ & 4 & 0.117 & 1.382 & 0.261 \\
\hline & $\mathrm{T} \times \mathrm{S}$ & 4 & 0.093 & 1.102 & 0.372 \\
\hline \multirow[t]{3}{*}{$D_{\mathrm{Ba}}$} & $\mathrm{T}$ & 1 & 0.002 & 0.349 & 0.559 \\
\hline & $\mathrm{S}$ & 4 & 0.020 & 4.391 & $0.006^{*}$ \\
\hline & $\mathrm{T} \times \mathrm{S}$ & 4 & 0.003 & 0.613 & 0.656 \\
\hline \multicolumn{6}{|c|}{ Trial 2} \\
\hline \multirow[t]{3}{*}{$D_{\mathrm{Sr}}$} & $\mathrm{T}$ & 1 & 0.014 & 10.785 & $0.002^{*}$ \\
\hline & S & 4 & 0.001 & 0.830 & 0.515 \\
\hline & $\mathrm{T} \times \mathrm{S}$ & 4 & 0.002 & 1.382 & 0.260 \\
\hline \multirow[t]{3}{*}{$D_{\mathrm{Mg}}$} & $\mathrm{T}$ & 1 & 0.000 & 0.152 & 0.699 \\
\hline & $\mathrm{S}$ & 4 & 0.000 & 1.899 & 0.132 \\
\hline & $\mathrm{T} \times \mathrm{S}$ & 4 & 0.000 & 0.928 & 0.459 \\
\hline \multirow[t]{3}{*}{$D_{\mathrm{Mn}}$} & $\mathrm{T}$ & 1 & 0.003 & 0.122 & 0.728 \\
\hline & $\mathrm{S}$ & 4 & 0.024 & 1.079 & 0.382 \\
\hline & $\mathrm{T} \times \mathrm{S}$ & 4 & 0.021 & 0.955 & 0.444 \\
\hline \multirow[t]{3}{*}{$D_{\mathrm{Ba}}$} & $\mathrm{T}$ & 1 & 0.006 & 0.734 & 0.397 \\
\hline & $\mathrm{S}$ & 4 & 0.037 & 4.932 & $0.003^{*}$ \\
\hline & $\mathrm{T} \times \mathrm{S}$ & 4 & 0.010 & 1.283 & 0.295 \\
\hline
\end{tabular}

(Limburg 2001), 0 to 3 in striped bass (Secor et al. 2001) and 0 to 5 in sea-run brown trout (Limburg et al. 2001). Although the range of $[\mathrm{Sr} / \mathrm{Ca}]_{\text {otolith }}$ varies among species, it can be reliably used to infer habitat residence among systems that have marked differences in water chemistry (underlying geology) (Munro et al. 2005). The same [Sr/Ca $]_{\text {otolith }}$ could result from cool, salty water or warmer, fresher water, although the relative magnitude of these effects within a given system (estuary) are likely to be less than the differences among systems (estuaries). The interaction between temperature and salinity, however, does complicate the prospect of retrospectively identifying individual fish transport pathways across heterogeneous water chemistries (i.e. estuaries) as a function of their otolith elemental signatures through time. Although $[\mathrm{Sr} / \mathrm{Ca}]_{\text {otolith }}$ alone may not be a reliable predictor of water temperature and salinity, when used in combination with other metals (i.e. $\left.[\mathrm{Ba} / \mathrm{Ca}]_{\text {otolith }}\right)$, it may be possible to use more precise predictive models to retrospectively identify individual fish transport pathways as a function of their otolith elemental signatures through time.

Field studies have been able to use a suite of elements to assign individual fish to unique nursery habitats (Gillanders \& Kingsford 1996, Thorrold et al. 1998, 2001). Detected differences are used to assign fish to their respective nursery areas, even though the mechanisms of incorporation or the influence of temperature and salinity are poorly understood. Given the complexity of the relationship between the water and the otolith, it would be difficult to discern temperature or salinity experienced by individual fish. Nevertheless, these results do not invalidate the approach of retrospectively classifying experienced environments; if different otolith signatures are found, then different environments were inhabited. The differences in water chemistry in the present study, which used filtered seawater from a single system mixed with well water and synthetic sea salts, are likely to be less than the differences in water chemistry experienced by fishes occupying different estuaries. Although individual species incorporate trace metals in their otoliths in different quantities (in absolute terms, e.g. Table 5), otolith chemistry is a function of water chemistry and as such can be used to infer previous environmental (habitat) history among environments (habitats) that differ in water chemistry, particularly when multiple elements are analyzed to differentiate otolith signatures. In cases where validation is impractical (endangered species) or impossible (historic samples/ forensic applications), otolith chemistry can still provide useful information.

Table 5. Comparison of partition coefficient $(D)$ ranges for $\mathrm{Sr}, \mathrm{Mg}, \mathrm{Mn}$, and $\mathrm{Ba}$, for tested temperature and salinity ranges, as reported in this study for Lutjanus griseus, as estimated from Elsdon \& Gillanders (2002) for Acanthopagurus butcheri, and from Martin et al. (2004) and Martin \& Thorrold (2005) for Leiostomus xanthurus

\begin{tabular}{|lccccrr|}
\hline Species & $\begin{array}{c}\text { Temp. } \\
\text { range }\left({ }^{\circ} \mathrm{C}\right)\end{array}$ & $\begin{array}{c}\text { Salinity } \\
\text { range }\end{array}$ & $D_{\mathrm{Sr}}$ & \multicolumn{1}{c|}{$D_{\mathrm{Mg}}$} & $D_{\mathrm{Mn}}$ \\
\hline Lutjanus griseus & $18-33$ & $5-45$ & $0.21-0.38$ & $7.65 \times 10^{-6}-8.91 \times 10^{-5}$ & $0.0176-1.02$ & $0.043-0.45$ \\
Acanthopagurus butcheri & $12-24$ & $5-30$ & $0.42-0.6$ & $0.0004-0.0005$ & $0.2-0.55$ & $0.26-0.79$ \\
Leiostomus xanthurus & $17-26$ & 15,25 & $0.20-0.43$ & $0.00014-0.001$ & $0.055-0.92$ & $0.11-1.23$ \\
\hline
\end{tabular}


The present study demonstrates the complex and poorly understood mechanisms driving the $[\mathrm{Me} / \mathrm{Ca}]_{\text {otolith }}$ to $[\mathrm{Me} / \mathrm{Ca}]_{\text {water }}$ relationship. Element incorporation and the effects of temperature and salinity on element incorporation differ among fish species, limiting the development of generalized models to predict water chemistry from otolith chemistry. Therefore, the data presented here underscore the necessity of validation experiments to translate species-specific elemental signatures in otoliths.

Acknowledgements. This research was supported by grants from the NOAA Sea Grant to S. Thorrold, J. Hare, S. Sponaugle, R. Cowen, and L. Barbieri, the NOAA South Florida Ecosystem Research and Monitoring Program funded jointly by NMFS SEFSC and NOS NCCOS, a grant in aid from the International Women's Fishing Association, and a PEO International Women's Organization Scholar Award to G.B.M. We thank Z. Chen (LITER, Old Dominion University) for assisting with the water samples, A. Jugovich (NOAA, National Ocean Service, CCFHR, Beaufort, North Carolina) for snapper rearing and tank maintenance, and S. Thorrold and J. Fitzgerald (Woods Hole Oceanographic Institution, Woods Hole, Massachustetts) for assisting with sample preparation and running the laser and ICP-MS. We also thank J. Hare, D. Ahrenholz, L. Settle, P. Marraro, B. Wells, C. Grimes, and 2 anonymous reviewers for comments that helped to significantly improve the manuscript. The views expressed herein are those of the authors and do not necessarily reflect the views of NOAA or any of its subagencies.

\section{LITERATURE CITED}

Allman RJ, Grimes CB (2002) Temporal and spatial dynamics of spawning, settlement, and growth of gray snapper (Lutjanus griseus) from the West Florida shelf as determined from otolith microstructures. Fish Bull 100:391-403

Bath GE, Thorrold SR, Jones CM, Campana SE, McLaren JW, Lam JWH (2000) Strontium and barium uptake in aragonitic otoliths of marine fish. Geochim Cosmochim Acta 64: 1705-1714

Beck MW, Heck KL Jr, Able KW, Childers DL and 9 others (2001) The identification, conservation, and management of estuarine and marine nurseries for fish and invertebrates. Bioscience 51:633-641

Buckel JA, Sharack BL, Zdanowicz VS (2004) Effect of diet on otolith composition in Pomatomus saltatrix, an estuarine piscivore. J Fish Biol 64:1469-1484

Campana SE (1999) Chemistry and composition of fish otoliths: pathways, mechanisms and applications. Mar Ecol Prog Ser 188:263-297

Chesney EJ, McKee BM, Blanchard T, Chan LH (1998) Chemistry of otoliths from juvenile menhaden Brevoortia patronus: evaluating strontium, strontium:calcium and strontium isotope ratios as environmental indicators. Mar Ecol Prog Ser 171:261-273

Chester AJ, Thayer GW (1990) Distribution of spotted seatrout (Cynoscion nebulosus) and gray snapper (Lutjanus griseus) juveniles in seagrass habitats of Western Florida Bay. Bull Mar Sci 46:345-357

Dahlgren CP, Eggleston DB (2000) Ecological processes underlying ontogenetic habitat shifts in a coral reef fish. Ecology 81:2227-2240
Daverat F, Limburg KE, Thibault I, Shiao JC and 5 others (2006) Phenotypic plasticity of habitat use by three temperate ell species Anguilla anguilla, A japonica and A. rostrata. Mar Ecol Prog Ser 308:231-241

Eggleston DB (1995) Recruitment in Nassau grouper Epinephelus striatus: post-settlement abundance, microhabitat features, and ontogenetic habitat shifts. Mar Ecol Prog Ser 124:9-22

Elsdon TS, Gillanders BM (2002) Interactive effects of temperature and salinity on otolith chemistry: challenges for determining environmental histories of fish. Can J Fish Aquat Sci 59:1796-1808

Elsdon TS, Gillanders BM (2003) Reconstructing migratory patterns of fish based on environmental influences on otolith chemistry. Rev Fish Biol Fish 13:219-235

Elsdon TS, Gillanders BM (2004) Fish otolith chemistry influenced by exposure to multiple environmental variables. J Exp Mar Biol Ecol 313:269-284

Farrell JA, Campana SE (1996) Regulation of calcium and strontium deposition on the otoliths of juvenile tilapia, Oreochromis niloticus. Comp Biochem Physiol 115A: 103-109

Gillanders BM, Kingsford MJ (1996) Elements in otoliths may elucidate the contribution of estuarine recruitment to sustaining coastal reef populations of a temperate reef fish. Mar Ecol Prog Ser 141:13-20

Gillanders BM, Kingsford MJ (2000) Elemental fingerprints of otoliths of fish may distinguish estuarine 'nursery' habitats. Mar Ecol Prog Ser 201:273-286

Hettler WF (1979) Modified neuston net for collecting live larval and juvenile fish. Prog Fish-Cult 41:32-33

Hoff GR, Fuiman LA (1995) Environmentally induced variation in elemental composition of red drum (Sciaenops ocellatus) otoliths. Bull Mar Sci 56:578-591

Jessop BM, Shiao JC, Iizuka Y, Tzeng WN (2002) Migratory behaviour and habitat use by American eels Anguilla rostrata as revealed by otolith microchemistry. Mar Ecol Prog Ser 233:217-229

Jones GP, McCormick MI (2002) Numerical and energetic processes in the ecology of coral reef fishes. In: Sale PF (ed) Coral reef fishes: dynamics and diversity in a complex ecosystem. Academic Press, San Diego, CA, p 221-238

Karnaky KJ Jr (1998) Osmotic and Ionic regulation. In: Evans DH (ed) The physiology of fishes, 2nd edn. CRC Press, Boca Raton, FL, p 157-176

Limburg KE (2001) Through the gauntlet again: demographic restructuring of American shad by migration. Ecology 82: 1584-1596

Limburg KE, Landergren P, Westin L, Elfman M, Kristiansson $P$ (2001) Flexible modes of anadromy in Baltic sea-trout (Salmo trutta): making the most of marginal spawning streams. J Fish Biol 59:682-695

Lindman HR (1974) Analysis of variance in complex experimental designs. WH Freeman, San Francisco, CA

Martin GB, Thorrold SR (2005) Temperature and salinity effects on magnesium, manganese, and barium incorporation in otoliths of larval and early juvenile spot Leiostomus xanthurus. Mar Ecol Prog Ser 293:223-232

Martin GB, Thorrold SR, Jones CM (2004) Temperature and salinity effects on strontium incorporation in otoliths of larval spot (Leiostomus xanthurus). Can J Fish Aquat Sci 61: $34-42$

Milton DA, Chenery SR (2001) Sources and uptake of trace metals in otoliths of juvenile barramundi (Lates calcarifer). J Exp Mar Biol Ecol 264:47-65

Morse JW, Bender ML (1990) Partition coefficients in calcite-examination of factors influencing the validity of 
experimental results and their application to natural systems. Chem Geol 82:265-277

Munro AR, McMahon TE, Ruzycki JR (2005) Natural chemical markers identify source and date of introduction of an exotic species: lake trout (Salvelinus namaycush) in Yellowstone Lake. Can J Fish Aquat Sci 62:79-87

Nagelkerken I, Dorenbosch M, Verberk WCEP, Cocheret de la Morinière E, van der Velde G (2000) Importance of shallow-water biotopes of a Caribbean bay for juvenile coral reef fishes: patterns in biotope association, community structure and spatial distribution. Mar Ecol Prog Ser 202: 175-192

Pawson MG (1990) Using otolith weight to age fish. J Fish Biol 36:521-531

Reznick D, Lindbeck E, Bryga H (1989) Slower growth results in larger otoliths: an experimental test with guppies (Poecilia reticulata). Can J Fish Aquat Sci 46:108-112

Rooker JR, Secor DH, Zdanowicz VS, Itoh T (2001) Discrimination of northern bluefin tuna from nursery areas in the Pacific Ocean using otolith chemistry. Mar Ecol Prog Ser 218:275-282

Rosenthal Y, Field MP, Sherrell RM (1999) Precise determination of element/calcium ratios in calcareous samples using sector field inductively coupled plasma mass spectrometry. Anal Chem 71:3248-3253

Ross SW, Moser ML (1995) Life history of juvenile gag, Myctoperca microlepis, in North Carolina estuaries. Bull Mar Sci 56:222-237

Secor DH (1992) Application of otolith microchemistry analysis to investigate anadromy in Chesapeake Bay striped bass Morone saxatilis. Fish Bull US 90:798-806

Secor DH, Dean JM (1989) Somatic growth effects on the otolith - fish size relationship in young pond-reared striped bass, Morone saxatilis. Can J Fish Aquat Sci 46: 113-121

Secor DH, Henderson-Arzapalo A, Piccoli PM (1995) Can otolith microchemistry chart patterns of migration and habitat utilization in anadromous fishes? J Exp Mar Biol Ecol 192:15-33

Editorial responsibility: Kenneth Sherman (Contributing Editor), Narragansett, Rhode Island, USA
Starck WAI, Schroeder RE (1970) Investigations on gray snapper (Lutjanus griseus). University of Miami Press, Coral Gables, FL

Thorrold SR, Jones CM, Swart PK, Targett TE (1998) Accurate classification of juvenile weakfish Cynoscion regalis to estuarine nursery areas based on chemical signatures in otoliths. Mar Ecol Prog Ser 173:253-265

Thorrold SR, Latkoczy C, Swart PK, Jones CM (2001) Natal homing in a marine fish. Science 291:297-299

Tzeng WN, Severin KP, Wickstroem H (1997) Use of otolith microchemistry to investigate the environmental history of European eel Anguilla anguilla. Mar Ecol Prog Ser 149: 73-81

Tzeng MW, Hare JA, Linquist DG (2003) Ingress of transformation stage gray snapper, Lutjanus griseus (Pisces: Lutjanidae) through Beaufort Inlet, North Carolina. Bull Mar Sci 72:891-908

Walther BD and Thorrold SR (2006) Water, not food, contributes the majority of strontium and barium deposited in the otoliths of a marine fish. Mar Ecol Prog Ser 311:125-130

Worthington DG, Doherty PJ, Fowler AJ (1995) Variation in the relationship between otolith weight and age: implications for the estimation of age of two tropical damselfish (Pomacentrus moluccensis and P. wardi). Can J Fish Aquat Sci 52:233-242

Wuenschel MJ, Jugovich AR, Hare JA (2004) Effect of temperature and salinity on energetics of juvenile gray snapper (Lutjanus griseus): implications for nursery habitat value. J Exp Mar Biol Ecol 312:333-347

Wuenschel MJ, Jugovich AR, Hare JA (2005) Metabolic response of juvenile gray snapper (Lutjanus griseus) to temperature and salinity: physiological cost of different environments. J Exp Mar Biol Ecol 321:145-154

Yoshinaga J, Nakama A, Morita M, Edmonds JS (2000) Fish otolith reference material for quality assurance of chemical analyses. Mar Chem 69:91-97

Zar JH (1999) Biostatistical analysis. Prentice Hall, Upper Saddle River, NJ

Submitted: August 6, 2005; Accepted: March 28, 2006 Proofs received from author(s): October 2, 2006 